Scientia Agricola

http://dx.doi.org/10.1590/0103-9016-2015-0114

\title{
Effects of glutamine on performance and intestinal mucosa morphometry of broiler chickens vaccinated against coccidiosis
}

\author{
Brenda Carla Luquetti, Miguel Frederico Fernandez Alarcon, Raquel Lunedo, Daniel Mendes Borges Campos, Renato Luís Furlan, \\ Marcos Macari*
}

São Paulo State University/FCAV - Dept. of Animal Morphology and Physiology, Via de Acesso Prof. P.D. Castellane, s/n - 14884-900 - Jaboticabal, SP - Brazil. *Corresponding author <macari@fcav.unesp.br>

Edited by: Gerson Barreto Mourão

\begin{abstract}
This study aimed to assess the effects of glutamine as feed additive on performance and intestinal mucosa morphometry of broiler chickens vaccinated against coccidiosis. A total of 400 day-old male chicks were randomly assigned to four treatments (NVNG - no vaccination, no glutamine supplementation; NVG - no vaccination, glutamine supplementation $\left(10 \mathrm{~g} \mathrm{~kg}^{-1}\right)$; VNG - vaccination, no glutamine supplementation; VG - vaccination, glutamine supplementation) replicated four times with 25 birds per replicate. A commercial sprayed-on vaccine against coccidiosis containing Eimeria acervulina, E. maxima, E. mivati, and E. tenella was administered at the hatchery. Broiler performance was evaluated from 1-28 days, and morphometric parameters were analyzed at 14,21 , and 28 days of age. Body weight gain and feed intake were negatively affected by vaccination, but not by glutamine. Vaccination increased crypt depth in the duodenum and jejunum at 21 and 28 days. In conclusion, this study showed that glutamine was not able to increase weight gain of broiler chickens, irrespective of whether the animals were vaccinated or not against coccidiosis. Glutamine supplementation was able to improve feed conversion in vaccinated birds suggesting trophic effect on intestinal epithelium improving. Keywords: anticoccidial vaccines, intestinal ephitelium, gut morphometry, glutamine supplementation, small intestine
\end{abstract}

Received March 23, 2015

Accepted November 02, 2015 ride show beneficial effects on reducing performance (Nollet et al., 2007) and epithelial cell losses (Luquetti et al., 2012) in vaccinated birds. Other additives such as herbal extracts (Allen, 2003), essential oil blends (Oviedo-Rondon et al., 2006) and probiotics (Stringfellow et al., 2011) also seem to protect the intestinal mucosa against mild coccidial infections generated by the vaccine. Biological mechanisms underlying the activity of these feed additives in maintaining broiler intestinal health include microbial community modulation, stimulus of villi growth and host immune system modulation. On the other hand, increase in protein levels of diet is another important tool to avoid performance decline in birds vaccinated against coccidiosis (Lee et al., 2011). The inclusion of some amino acids in diets for vaccinated birds, like arginine (Perez-Carbajal et al., 2010), glycine, serine and proline (Lehman et al., 2009), which act in the immune system and mucin production, respectively, also results in better performance compared to animals vaccinated and not supplied. Alternatively, because glutamine is an important energy source for enterocyte development (Fujita and Sakurai, 1995), it may also be used as a nutritional management tool for intestinal mucosa repair in vaccinated birds.

Since anticoccidial vaccine causes intestinal epithelial lesions (Scheurer et al., 2013) and glutamine acts as an important epithelial growth, repairing energy source (Pohlenz et al., 2012; Soltan, 2009), this study aimed to assess the effects of glutamine as feed additive on performance and intestinal mucosa development of broiler chickens vaccinated against coccidiosis. 


\section{Materials and Methods}

This experiment was conducted according the rules of the National Council for Animal Experiments Control (CONCEA) and was approved by the Animal Ethics Committee (CEUA).

Four hundred day-old male Cobb $500^{\mathrm{TM}}$ broiler chicks were raised in floor pens with wood shavings as litter and reared in an environmentally controlled room where ambient temperatures were kept at thermoneutrality according to bird age and air relative humidity (RH) between 45 and $65 \%$, within the standards of the line (COBB, 2003). At day one, the birds were assigned to four groups and submitted to the following treatments: NVNG - no vaccination and no glutamine supplementation; NVG - no vaccination, with glutamine supplementation; VNG - vaccination and no glutamine supplementation; and VG - vaccination and glutamine supplementation. Each treatment was replicated four times with 25 birds per replicate.

The experimental diets were formulated based on corn and soybean meal with $220 \mathrm{~g} \mathrm{~kg}^{-1}$ crude protein $(\mathrm{CP})$ and $12.13 \mathrm{MJ}$ metabolizable energy (ME) $\mathrm{kg}^{-1}$ (NRC, 1994). Glutamine (10 $\mathrm{g} \mathrm{kg}^{-1}$ ) was added to NVG and VG diets in replacement of kaolin, and birds were fed ad libitum throughout the experimental period (Table 1). Vaccine against coccidiosis contained live and attenuate oocysts of Eimeria acervulina, E. maxima, E. mivati, and $E$. tenella. The vaccine was administered at day one and the dosage followed the manufacturer's recommendation for application via spray (chicks were inside a vaccine box). Body weight gain (BWG, g), feed intake (FI, $\mathrm{g})$, and feed conversion ratio (FCR, $\mathrm{g} \mathrm{g}^{-1}$ ) were measured at seven, 14,21 , and 28 days.

At 14,21 , and 28 days of age, five birds from each replicate were fasted for $12 \mathrm{~h}$ (according to Torres et al., 2013) and euthanized by $\mathrm{CO}_{2}$ asphyxiation. Then, samples approximately $2 \mathrm{~cm}$ long were collected from the middle part of each small intestine segment (duodenum: from pylorus to distal duodenal loop; jejunum: from distal duodenal loop to Meckel's diverticulum; and ileum: between Meckel's diverticulum and the caeca opening) for morphometric analysis of the mucosa. Samples were fixed in Bouin solution for $24 \mathrm{~h}$, dehydrated with a standard alcohol-toluene sequence and embedded in plastic paraffin for the morphometric analysis. Then, 5- $\mu \mathrm{m}$ tissue sections were prepared and stained with hematoxylin-eosin according to Behmer (1976). Each histological slide was composed of five sections from the same segment and animal, and between one section and another, the minimum distance of $200 \mu \mathrm{m}$ was necessary. Villus height $(\mathrm{VH}, \mu \mathrm{m})$ and crypt depth $(\mathrm{CD}, \mu \mathrm{m})$ from each segment were measured in 70 microscopic fields (14 for each slide) using an image analysis system. Villus:crypt ratio $(\mathrm{V} / \mathrm{C})$ was also calculated for each intestinal segment.

Data were analyzed in a completely randomized design in a two (with/without coccidiosis vaccination) $\times$ two (with/without glutamine supplementation) factorial arrangement using the general linear model procedure of SAS software (SAS Institute, 2011). Differences between treatment means were checked for significance using the Tukey test at $5 \%$ significance.

\section{Results}

Broiler performance up to 28 days of age is shown in Table 2 . There were no differences $(p>0.05)$ in broiler performance among the treatments up to seven days of age. However, after that period, BWG (1-14, 1-21, and 1-28 days) and FI (1-21 and 1-28 days) were significantly decreased, while FCR (1-21 days) was significantly increased in vaccinated treatments. The vaccine $\times$ glutamine interaction was significant for FCR from 1-14 days ( $p=0.03$ ) (Table 3). Vaccine did not affect feed conversion in glutamine-fed birds, while in birds not fed with glutamine, higher feed conversion was found in vaccinated ones. Glutamine did not affect feed conversion in non-vaccinated birds, while higher FCR was found in vaccinated birds not fed with glutamine.

Table 1 - Diet composition percentage and calculated nutrient values of experimental broiler diets.

\begin{tabular}{|c|c|c|}
\hline \multirow[t]{2}{*}{ Ingredients $\left(\mathrm{g} \mathrm{kg}^{-1}\right)$} & \multicolumn{2}{|c|}{ Treatments } \\
\hline & NVNG and & 1 NVG and VG \\
\hline Corn & 524.2 & 524.2 \\
\hline Soybean meal & 397.2 & 397.2 \\
\hline Soybean oil & 25.6 & 25.6 \\
\hline Dicalcium phosphate & 16.1 & 16.1 \\
\hline $\mathrm{CaCO}_{3}$ & 14.0 & 14.0 \\
\hline $\mathrm{NaCl}$ & 4.1 & 4.1 \\
\hline Supplement ${ }^{2}$ & 6.5 & 6.5 \\
\hline DL-methionine & 2.3 & 2.3 \\
\hline L-glutamine $^{3}$ & 0.0 & 10.0 \\
\hline Kaolin & 10.0 & 0.0 \\
\hline \multicolumn{3}{|c|}{ Nutritional composition $\left(\mathrm{g} \mathrm{kg}^{-1}\right.$ ) unless noted ${ }^{4}$} \\
\hline Metabolizable energy (MJ kg-1) & \multicolumn{2}{|c|}{12.13} \\
\hline Crude protein & \multicolumn{2}{|c|}{220.0} \\
\hline Calcium & \multicolumn{2}{|c|}{10.0} \\
\hline Available phosphorus & \multicolumn{2}{|c|}{5.0} \\
\hline Sodium & \multicolumn{2}{|c|}{2.0} \\
\hline Methionine & \multicolumn{2}{|c|}{5.0} \\
\hline Methionine+cysteine & \multicolumn{2}{|c|}{8.8} \\
\hline Lysine & \multicolumn{2}{|c|}{11.3} \\
\hline \multicolumn{3}{|c|}{$\begin{array}{l}\text { 'NVNG: no vaccination and no glutamine supplementation; NVG: no } \\
\text { vaccination, with glutamine supplementation; VNG: vaccination and no } \\
\text { glutamine supplementation; VG: vaccination and glutamine supplementation. } \\
\text { 2Mineral and vitamin supplement as the quantity added for each } \mathrm{kg} \text { of feed. } \\
\text { Vitamin. A: } 7000 \mathrm{IU} \text {; vitamin D3: } 1400 \text { IU; vitamin E: } 19.5 \mathrm{IU} \text {; vitamin K: } 1.5 \\
\mathrm{mg} \text {; vitamin B1: } 0.6 \mathrm{mg} \text {; vitamin B2: } 2.36 \mathrm{mg} \text {; vitamin B6: } 0.6 \mathrm{mg} \text {; vitamin } \\
\text { B12: } 1.32 \mathrm{mcg} \text {; Biotin: } 0.15 \mathrm{mg} \text {; Choline: } 1.54 \text { g; Pantothenic acid: } 9.32 \mathrm{mg} \text {; } \\
\text { Niacin: } 30.12 \mathrm{mg} \text {; Folic acid: } 1.42 \mathrm{mg} \text {; Selenium: } 0.65 \mathrm{mg} \text {; lodine: } 0.35 \mathrm{mg} \text {; } \\
\text { Iron: } 57.72 \mathrm{mg} \text {; Copper: } 12.3 \mathrm{mg} \text {; Zinc: } 141.48 \mathrm{mg} \text {; Manganese: } 173 \mathrm{mg} \text {; } \\
\text { Potassium: } 7.88 \text { g; Sodium: } 1.80 \mathrm{~g} \text {; Sulphur: } 0.72 \mathrm{~g} \text {; Magnesium: } 0.90 \mathrm{~g} \text {. } \\
\text { } \text { Supplemental Glutamine was added to the test diets at the expense of the } \\
\text { inert filler (kaolin) to derive dietary treatments. }{ }^{4} \text { Calculated composition using } \\
\text { data from the Brazilian Tables for Poultry and Swine (Rostagno et al., 2011). }\end{array}$} \\
\hline
\end{tabular}


Table 2 - Growth performance of broilers from 1 to 28 days.

\begin{tabular}{|c|c|c|c|c|c|c|c|c|c|c|c|c|}
\hline \multirow[b]{3}{*}{ Vaccine $^{2}$} & \multicolumn{3}{|c|}{$1-7$ days } & \multicolumn{3}{|c|}{ 1-14 days } & \multicolumn{3}{|c|}{ 1-21 days } & \multicolumn{3}{|c|}{$1-28$ days } \\
\hline & BWG $^{1}$ & $\mathrm{Fl}$ & FCR & BWG & $\mathrm{Fl}$ & FCR & BWG & $\mathrm{FI}$ & FCR & BWG & $\mathrm{Fl}$ & FCR \\
\hline & & & & & & & & & & & & \\
\hline V & $122 \pm 23$ & $127 \pm 12$ & $1.04 \pm 0.04$ & $407 \pm 23 b$ & $525 \pm 25$ & $1.26 \pm 0.06$ & $735 \pm 35 b$ & $1029 \pm 37 b$ & $1.39 \pm 0.07 a$ & $1213 \pm 36 b$ & $1796 \pm 65 b$ & $1.48 \pm 0.07$ \\
\hline NV & $124 \pm 21$ & $133 \pm 21$ & $1.06 \pm 0.03$ & $430 \pm 14 a$ & $529 \pm 21$ & $1.23 \pm 0.06$ & $850 \pm 24 a$ & $1106 \pm 56 a$ & $1.30 \pm 0.05 b$ & $1346 \pm 45 a$ & $1938 \pm 79 a$ & $1.44 \pm 0.04$ \\
\hline Glutamin & & & & & & & & & & & & \\
\hline G & $123 \pm 11$ & $129 \pm 9$ & $1.04 \pm 0.03$ & $424 \pm 34$ & $534 \pm 10$ & $1.23 \pm 0.04$ & $833 \pm 21$ & $1122 \pm 23$ & $1.34 \pm 0.06$ & $1331 \pm 45$ & $1930 \pm 56$ & $1.45 \pm 0.06$ \\
\hline NG & $122 \pm 12$ & $131 \pm 10$ & $1.07 \pm 0.03$ & $423 \pm 21$ & $533 \pm 15$ & $1.26 \pm 0.03$ & $822 \pm 12$ & $1133 \pm 33$ & $1.36 \pm 0.04$ & $1338 \pm 34$ & $1966 \pm 55$ & $1.47 \pm 0.04$ \\
\hline & & & & & & & $p$ values & & & & & \\
\hline V & 0.33 & 0.20 & 0.26 & $<0.01$ & 0.09 & 0.05 & $<0.01$ & 0.04 & $<0.01$ & $<0.01$ & $<0.01$ & 0.17 \\
\hline G & 0.71 & 0.54 & 0.18 & 0.11 & 0.91 & 0.16 & 0.70 & 0.62 & 0.35 & 0.99 & 0.48 & 0.40 \\
\hline$V \times G$ & 0.51 & 0.71 & 0.23 & 0.96 & 0.16 & 0.03 & 0.51 & 0.14 & 0.39 & 0.42 & 0.18 & 0.39 \\
\hline $\mathrm{CV}^{3}(\%)$ & 4.31 & 7.25 & 4.58 & 3.02 & 3.49 & 2.35 & 3.69 & 3.39 & 3.38 & 3.43 & 4.27 & 3.64 \\
\hline
\end{tabular}

Data are expressed as means \pm standard deviations. Means within a column with different superscripts are significantly different $(p<0.05)$. ${ }^{1} B W G=B$ Body weight gain (g); Fl = feed intake (g); FCR = feed conversion ratio $\left(\mathrm{g} \mathrm{g}^{-1}\right)$. ${ }^{2}$ Broiler chickens fed (G)/not fed (NG) L-glutamine (10 g kg $\left.{ }^{-1}\right)$ and vaccinated (V) or not (NV) against coccidiosis. ${ }^{3} \mathrm{CV}$ : Coefficient of variation.

Table 3 - Vaccine $\times$ glutamine interaction on feed conversion ratio (FCR, $\mathrm{g} \mathrm{g}^{-1}$ ) from 1-14 days of age.

\begin{tabular}{lccc}
\hline & & \multicolumn{2}{c}{ Vaccine $^{1}$} \\
\hline & & $\mathrm{NV}$ & $\mathrm{V}$ \\
\cline { 3 - 4 } Glutamine $^{1}$ & $\mathrm{NG}$ & $1.23 \mathrm{Ba}$ & $1.29 \mathrm{Aa}$ \\
& $\mathrm{G}$ & $1.23 \mathrm{Aa}$ & $1.23 \mathrm{Ab}$ \\
\hline
\end{tabular}

Means followed by the same capital letters in the same row and small letters in the same column are not different according the Tukey test at $5 \%$ of probability level. ${ }^{1}$ Broiler chickens fed (G)/not fed (NG) L-glutamine (10 $\left.\mathrm{g} \mathrm{kg}^{-1}\right)$ and vaccinated (V) or not (NV) against coccidiosis.

The effects of vaccination and glutamine supplementation on villus height, crypt depth and villus:crypt ratio are shown in Table 4 . There were no differences in intestinal villus height among treatments $(p>0.05)$ in any intestinal segment at 14 days of age, except for ileum villus height in which an interaction was observed $(p$ $=0.04)$. The non-vaccinated birds showed higher villus height in the ileum than the vaccinated ones, for both groups, fed or not fed with glutamine (Table 5). Glutamine did not affect the villus height in vaccinated birds, while higher villus height was found in non-vaccinated birds fed with glutamine. At jejunum (Table 4), the crypts were deeper and, consequently, the villus:crypt ratio was lower in vaccinated birds compared to control (non-vaccinated) birds $(p<0.05)$.

The effect of vaccination on mucosa parameters in the small intestine persisted at 21 days of age, affecting crypt depth (duodenum and ileum) $(p<0.01)$ and villus:crypt ratio (duodenum and jejunum) ( $p<0.01)$, with greater crypt depth values and lower villus:crypt ratio in vaccinated birds in comparison to non-vaccinated birds (Table 4). The vaccine $\times$ glutamine interaction was significant for crypt depth in the jejunum ( $p=0.03)$. In birds not fed with glutamine, jejunum crypt depth was higher in vaccinated than in non-vaccinated birds, while in birds fed with glutamine, the vaccination did not affect the crypt depth (Table 5). Glutamine did not affect the crypt depth in non-vaccinated birds, while higher crypt depth was found in vaccinated birds not fed with glutamine. The vaccine $\times$ glutamine interaction was also significant for villus height in the ileum $(p$ $=0.04)$. In birds fed with glutamine, ileum villus height was higher in non-vaccinated than in vaccinated birds, while in birds not fed with glutamine, the vaccination did not affect the villus height. Glutamine did not affect the villus height in vaccinated birds, while a higher villus height was found in non-vaccinated birds fed with glutamine (Table 5).

The effect of vaccination against coccidiosis was still detectable at 28 days of age (Table 4), with greater crypt depth and lower villus:crypt ratio values in the duodenum of vaccinated broilers than in non-vaccinated ones $(p<0.01)$. In the jejunum, villus height was lower $(p=0.03)$ in vaccinated birds than in non-vaccinated. A main effect of glutamine on jejunum villus height was also observed ( $p=0.03)$, with higher villus in glutaminefed birds. There was a significant interaction between glutamine and vaccine with respect to jejunum crypt depth $(p=0.03)$. In birds not fed with glutamine, jejunum crypt depth was higher in vaccinated than in non-vaccinated birds, while in glutamine-fed birds, vaccination did not affect the crypt depth. Glutamine did not affect the crypt depth in non-vaccinated birds, while higher crypt depth was found in vaccinated birds not fed with glutamine (Table 5).

\section{Discussion}

Due to chemotherapeutic costs and the impending threat of antibiotic bans, researchers are continuously evaluating alternative methods of coccidiosis control. Thus, the use of coccidia oocyst vaccines is a common management procedure to avoid losses in poultry farms, since they provide immunity to secondary exposure of the same Eimeria spp. (Williams, 2002; Yi et al., 2005). However, coccidiosis vaccina- 
Table 4 - Morphometric analysis of the mucosa of broilers at 14, 21 and 28 days.

\begin{tabular}{|c|c|c|c|c|c|c|c|c|c|}
\hline & \multicolumn{3}{|c|}{ Duodenum } & \multicolumn{3}{|c|}{ Jejunum } & \multicolumn{2}{|c|}{ Ileum } & \multirow[b]{2}{*}{$\mathrm{V} / \mathrm{C}$} \\
\hline & $\mathrm{VH}^{1}$ & $C D$ & $\mathrm{~V} / \mathrm{C}$ & $\mathrm{VH}$ & $C D$ & $\mathrm{~V} / \mathrm{C}$ & $\mathrm{VH}$ & $C D$ & \\
\hline & \multicolumn{8}{|c|}{14 days } & \\
\hline \multicolumn{10}{|l|}{ Vaccine $^{2}$} \\
\hline V & $1211 \pm 21$ & $250 \pm 12$ & $4.8 \pm 0.9$ & $961 \pm 23$ & $236 \pm 12 a$ & $4.0 \pm 0.5 b$ & $701 \pm 26$ & $243 \pm 22 a$ & $2.8 \pm 0.3$ \\
\hline $\begin{array}{l}\text { NV } \\
\text { Glutamine }\end{array}$ & $1308 \pm 43$ & $217 \pm 13$ & $6.0 \pm 0.8$ & $1024 \pm 43$ & $192 \pm 11 b$ & $5.3 \pm 0.3 a$ & $893 \pm 33$ & $205 \pm 41 b$ & $4.3 \pm 0.4$ \\
\hline G & $1292 \pm 33$ & $217 \pm 18$ & $5.9 \pm 1.0$ & $1104 \pm 37$ & $234 \pm 20$ & $4.7 \pm 0.5$ & $850 \pm 12$ & $231 \pm 25$ & $4.2 \pm 0.6$ \\
\hline$N G$ & $1227 \pm 29$ & $250 \pm 33$ & $4.9 \pm 0.7$ & $881 \pm 29$ & $194 \pm 14$ & $4.5 \pm 0.3$ & $744 \pm 22$ & $211 \pm 35$ & $3.8 \pm 0.5$ \\
\hline \multicolumn{10}{|c|}{$p$ values } \\
\hline V & 0.19 & 0.78 & 0.38 & 0.09 & $<0.01$ & 0.02 & 0.53 & 0.05 & 0.17 \\
\hline G & 0.80 & 0.24 & 0.49 & 0.05 & 0.66 & 0.11 & 0.97 & 0.30 & 0.83 \\
\hline$V \times G$ & 0.71 & 0.25 & 0.50 & 0.21 & 0.23 & 0.79 & 0.04 & 0.50 & 0.15 \\
\hline $\mathrm{CV}^{3}(\%)$ & 24.28 & 25.28 & 30.37 & 24.07 & 15.78 & 24.69 & 35.17 & 17.39 & 37.91 \\
\hline \multicolumn{10}{|c|}{21 days } \\
\hline \multicolumn{10}{|l|}{ Vaccine } \\
\hline V & $1419 \pm 33$ & $379 \pm 22 a$ & $3.7 \pm 0.5 b$ & $1039 \pm 29$ & $272 \pm 21$ & $3.8 \pm 0.4 b$ & $838 \pm 25$ & $231 \pm 22 \mathrm{a}$ & $3.6 \pm 0.7$ \\
\hline $\begin{array}{l}\text { NV } \\
\text { Glutamine }\end{array}$ & $1451 \pm 41$ & $234 \pm 12 b$ & $6.2 \pm 0.6 \mathrm{a}$ & $1096 \pm 33$ & $187 \pm 13$ & $5.8 \pm 0.6 a$ & $926 \pm 34$ & $170 \pm 12 b$ & $5.4 \pm 0.9$ \\
\hline$G$ & $1500 \pm 87$ & $297 \pm 32$ & $5.0 \pm 0.9$ & $1055 \pm 91$ & $198 \pm 56$ & $5.3 \pm 0.7$ & $932 \pm 67$ & $195 \pm 23$ & $4.7 \pm 0.9$ \\
\hline$N G$ & $1420 \pm 65$ & $316 \pm 23$ & $4.4 \pm 0.7$ & $1080 \pm 76$ & $261 \pm 45$ & $4.1 \pm 0.5$ & $842 \pm 76$ & $199 \pm 21$ & $4.2 \pm 0.4$ \\
\hline \multicolumn{10}{|c|}{$p$ values } \\
\hline V & 0.21 & $<0.01$ & $<0.01$ & 0.54 & 0.18 & $<0.01$ & 0.06 & $<0.01$ & 0.05 \\
\hline G & 0.22 & 0.43 & 0.27 & 0.75 & 0.05 & 0.24 & 0.22 & 0.71 & 0.52 \\
\hline$V \times G$ & 0.62 & 0.56 & 0.39 & 0.53 & 0.03 & 0.21 & 0.04 & 0.30 & 0.47 \\
\hline $\mathrm{CV}^{3}(\%)$ & 9.46 & 16.14 & 22.31 & 19.57 & 23.65 & 20.99 & 9.61 & 17.39 & 17.74 \\
\hline \multicolumn{10}{|c|}{28 days } \\
\hline Vaccine & & & & & & & & & \\
\hline V & $1444 \pm 88$ & $325 \pm 12 a$ & $4.4 \pm 0.7 b$ & $1099 \pm 76 b$ & $269 \pm 36$ & $4.0 \pm 0.4$ & $1038 \pm 102$ & $196 \pm 34$ & $5.2 \pm 0.8$ \\
\hline $\begin{array}{l}\text { NV } \\
\text { Glutamine }\end{array}$ & $1583 \pm 76$ & $256 \pm 23 b$ & $6.1 \pm 0.4 a$ & $1240 \pm 55 a$ & $203 \pm 12$ & $6.0 \pm 0.8$ & $1050 \pm 99$ & $194 \pm 23$ & $5.4 \pm 0.7$ \\
\hline G & $1545 \pm 67$ & $288 \pm 34$ & $5.3 \pm 0.6$ & $1238 \pm 89 a$ & $218 \pm 22$ & $5.6 \pm 0.7$ & $1060 \pm 78$ & $203 \pm 23$ & $5.2 \pm 0.8$ \\
\hline$N G$ & $1481 \pm 88$ & $293 \pm 21$ & $5.0 \pm 0.5$ & $1101 \pm 80 b$ & $251 \pm 21$ & $4.3 \pm 0.6$ & $1028 \pm 65$ & $187 \pm 18$ & $5.4 \pm 0.7$ \\
\hline \multicolumn{10}{|c|}{$p$ values } \\
\hline V & 0.57 & $<0.01$ & $<0.01$ & 0.03 & $<0.01$ & 0.15 & 0.88 & 0.96 & 0.99 \\
\hline G & 0.35 & 0.79 & 0.74 & 0.03 & 0.11 & 0.78 & 0.76 & 0.41 & 0.57 \\
\hline$V \times G$ & 0.06 & 0.86 & 0.30 & 0.66 & 0.03 & 0.05 & 0.13 & 0.17 & 0.17 \\
\hline $\mathrm{CV}^{3}(\%)$ & 9.98 & 13.39 & 17.64 & 10.64 & 17.42 & 19.41 & 22.49 & 19.76 & 16.59 \\
\hline
\end{tabular}

Table 5 - Vaccine $\times$ glutamine interaction for morphometric analysis of the mucosa of broilers.

\begin{tabular}{|c|c|c|c|c|c|}
\hline & \multirow{2}{*}{ Glutamine $^{1}$} & \multicolumn{4}{|c|}{ Vaccine $^{1}$} \\
\hline & & NV & V & NV & V \\
\hline & & $21 \mathrm{~d}$ & days & $28 d$ & days \\
\hline \multirow[t]{3}{*}{ Jejunum crypt depth ( $\mu \mathrm{m})$} & $N G$ & $189 \mathrm{Ba}$ & $322 \mathrm{Aa}$ & $198 \mathrm{Ba}$ & $304 \mathrm{Aa}$ \\
\hline & G & $184 \mathrm{Aa}$ & $210 \mathrm{Ab}$ & $209 \mathrm{Aa}$ & $226 \mathrm{Ab}$ \\
\hline & & $14 \mathrm{~d}$ & days & $21 \mathrm{~d}$ & days \\
\hline \multirow[t]{2}{*}{ lleum villus height $(\mu \mathrm{m})$} & $N G$ & $807 \mathrm{Ab}$ & $680 \mathrm{Ba}$ & $860 \mathrm{Ab}$ & $824 \mathrm{Aa}$ \\
\hline & G & $979 \mathrm{Aa}$ & $721 \mathrm{Ba}$ & $992 \mathrm{Aa}$ & $852 \mathrm{Ba}$ \\
\hline
\end{tabular}

Means followed by the same capital letters in the same row and small letters in the same column are not different according the Tukey test at $5 \%$ of probability level. 'Broiler chickens fed (G)/not fed (NG) L-glutamine (10 $\mathrm{g} \mathrm{kg}^{-1}$ ) and vaccinated (V) or not (NV) against coccidiosis. tion affects broiler performance during the transient infection period (Lehman et al., 2009; Orengo et al., 2012; Walk et al., 2011). In this study, BWG, FI and FCR were significantly affected by vaccine from day one until 21, and these results can be attributed to the effects of Eimeria in intestinal mucosa integrity and, consequently, the digestion and absorption of nutrients (Chapman et al., 2002; Nollet et al., 2007). From one to 28 days, there was no difference in FCR, but the BWG continued lower in vaccinated birds. Lehman et al. (2009) found similar results from zero to eight weeks, showing that, due the high growth rate and short rearing period, full recovery of the weight gain losses during the period of transient infection was not accomplished. 
Due to its effect on epithelial cells, glutamine has been used to protect or repair the intestinal mucosa (Hulst et al., 1993; Wilmore et al., 1988). Our data show that glutamine did not affect performance parameters. Other studies also reported no effect of L-glutamine $\left(10 \mathrm{~g} \mathrm{~kg}^{-1}\right)$ on broiler BWG and FCR up to market age (42 days) (Maiorka et al., 2000; Murakami et al., 2007). The findings of Yi et al. (2005) were similar to those described by Maiorka et al. (2000), as feeding $1 \%$ L-glutamine from the first day of life affected BWG only during the initial growth phase. This effect might be related to the increase in villus height of the intestinal mucosa, which can occur due to increased digestion and nutrient absorption (Pluske et al., 1996) during this period of high nutrient demand. However, after that period and without mucosal challenge, no effects of glutamine on performance are expected (Newsholme, 2001).

Glutamine is also the most important energy substrate for rapidly dividing cells (Blachier et al., 2009; Newsholme, 2001) and several studies have reported that L-glutamine supplementation $\left(10 \mathrm{~g} \mathrm{~kg}^{-1}\right)$ in broiler chicken diets enlarges the villus of the small intestine epithelium (Maiorka et al., 2000; Murakami et al., 2007; Sakamoto et al., 2006; Soltan, 2009). Our findings support the effects of glutamine on villus and crypt development in the small intestine: increased villus height and reduced crypt depth, suggesting that glutamine has, indeed, a trophic effect on intestinal epithelium reducing the eventual damage caused by vaccination against coccidiosis. Glutamine supplementation may have increased cell division at crypts and, thus, accelerated the damage repair in the intestinal mucosa caused by the parasite replication in the enterocytes. Indeed, an increased enterocyte migration rate in previous, mid and posterior intestinal sections was verified in juvenile channel catfish supplemented with glutamine (Pohlenz et al., 2012).

Several mechanisms have been proposed for glutamine activity such as higher production of polyamines that act on intestinal mucosa repair (Wang et al., 1998) and lower enterocyte apoptosis in rat and fish (Chow and Zhang, 1998; Jiang et al., 2009). Rhoads et al. (1997) also suggested that glutamine stimulates cell proliferation in the intestinal mucosa by increasing $\mathrm{Na}^{+} / \mathrm{H}^{+}$exchange in the plasma membrane and ornithine decarboxylase activity, which is responsible for mitochondrial membrane integrity and enterocyte development. Other authors have also suggested that glutamine plays an important role in cell structure and mucosa integrity, keeping the tight junction and permeability of the mucosa (Panigrahi et al., 1997) and increasing villus size (Maiorka et al., 2000), consequently, expanding the surface area for absorption (Pluske et al., 1996).

In conclusion, this study showed that glutamine alone was not able to increase performance of broiler chickens, irrespective of whether the animals were vaccinated or not against coccidiosis. On the other hand, glutamine supplementation was able to improve feed conversion in vaccinated birds suggesting the trophic effect on intestinal epithelium.

\section{Acknowledgments}

This work was supported by Coordination for the Improvement of Higher Level Personnel (CAPES), São Paulo State Foundation for Research Support (FAPESP), and Brazilian National Council for Scientific and Technological Development (CNPq).

\section{References}

Arczewska-Włosek, A.; Świątkiewicz, S. 2014. Nutritional as a modulatory fator of the efficacy of live anticoccidial vacines in broiler chickens. World's Poultry Science Journal 70: 81-92.

Allen, P.C. 2003. Dietary supplementation with Echinacea and development of immunity to challenge infection with coccidia. Parasitology Research 91: 74-78.

Behmer, O.A. 1976. Manual Techniques to Normal and Pathological Histology $=$ Manual de Técnicas para Histologia Normal e Patológica. Editora EDART/USP, São Paulo, SP, Brazil (in Portuguese).

Blachier, F.; Boutry, C.; Bos, C.; Tomé, D. 2009. Metabolism and functions of L-glutamate in the epithelial cells of the small and large intestines. The American Journal of Clinical Nutrition 90: 814S-821S.

Chapman, H.D.; Cherry, T.E.; Danforth, H.D.; Richards, G.; Shirley, M.W.; Williams, R.B. 2002. Sustainable coccidiosis control in poultry production: the role of live vaccines. International Journal for Parasitology 32: 617-629.

Chow, A.; Zhang, R. 1998. Glutamine reduces heat shock-induced cell death in rat intestinal epithelial cells. The Journal of Nutrition 128: 1296-301.

Cobb Vantress [COBB]. 2003. Cobb 500 Broiler Management Guide. COBB, Guapiaçu, SP, Brazil.

Fujita, T.; Sakurai, K. 1995. Efficacy of glutamine enriched enteral nutrition in an experimental model of mucosal ulcerative colitis. British Journal of Surgery 82: 749-751.

Hulst, R.R. van der; Meyenfeldt, M. von; Deutz, N.; Soeters, P.; Brummer, R.; Kreel, B. von; Arends, J. 1993. Glutamine and the preservation of gut integrity. The Lancet 341: 1363-1365.

Jiang, J.; Zheng, T.; Zhou, X.Q.; Liu, Y.; Feng, L. 2009. Influence of glutamine and vitamin $\mathrm{E}$ on growth and antioxidant capacity of fish enterocytes. Aquaculture Nutrition 15: 409-414.

Kawazoe, U.; Bordin, E.L.; de Lima, C.A.; Dias, L.A. 2005. Characterisation and histopathological observations of a selected Brazilian precocious line of Eimeria acervulina. Veterinary Parasitology 131: 5-14.

Lee, J.T.; Eckert, N.H.; Ameiss, K.A.; Stevens, S.M.; Anderson, P.N.; Anderson, S.M.; Barri, A.; McElroy, A.P.; Danforth, H.D.; Caldwell, D.J. 2011. The effect of dietary protein level on performance characteristics of coccidiosis vaccinated and nonvaccinated broilers following mixed-species Eimeria challenge. Poultry Science 90: 1916-1925.

Lehman, R.; Moran, E.T.; Hess, J.B. 2009. Response of coccidiostatversus vaccination- protected broiler to gelatin inclusion in high and low crude protein diets. Poultry Science 88: 984-993.

Long, P.L.; Johnson, J.; McKenzie, M.E.; Perry, E.; Crane, M.S.; Murray, P.K. 1986. Immunisation of young broiler chickens with low level infections of Eimeria tenella, E. acervulina or $E$. maxima. Avian Pathology 15: 271-278. 
Luquetti, B.C.; Furlan, R.L.; Fernandez-Alarcon, M.F.; Macari, M. 2012. Saccharomyces cerevisiae cell wall dietary supplementation on the performance and intestinal mucosa development and integrity of broiler chickens vaccinated against coccidiosis. Brazilian Journal of Poultry Science 14: 89-95.

Maiorka, A.; Silva, A.; Santin, E.; Borges, S.; Boleli, I.; Macari, M. 2000. Influence of glutamine supplementation on performance and intestinal villous and crypt development in broiler chickens. Arquivo Brasileiro de Medicina Veterinária e Zootecnia 52: 487-490 (in Portuguese, with abstract in English).

Murakami, A.; Sakamoto, M.; Natali, M.; Souza, L.; Franco, J. 2007. Supplementation of glutamine and vitamin $\mathrm{E}$ on the morphometry of the intestinal mucosa in broiler chickens. Poultry Science 86: 488-495.

Newsholme, P. 2001. Why is L-glutamine metabolism important to cells of the immune system in health, postinjury, surgery or infection? The Journal of Nutrition 131: 2515S-2522S.

Nollet, L.; Huyghebaert, G.; Spring, P. 2007. Effect of dietary mannan oligosaccharide (Bio-Mos) on live performance of broiler chickens given an anticoccidial vaccine (Paracox) followed by a mild coccidial challenge. The Journal of Applied Poultry Research 16: 397-403.

National Research Council [NRC]. 1994. Nutrient Requirements of Poultry. 9ed. NRC, Washington, DC, USA.

Orengo, J.; Buendía, A.J.; Ruiz-Ibáñez, M.R.; Madrid, J.; Del Río, L.; Catalá-Gregori, P.; García, V.; Hernández, F. 2012. Evaluating the efficacy of cinnamaldehyde and Echinacea purpurea plant extract in broilers against Eimeria acervulina. Veterinary Parasitology 185: 158-163.

Oviedo-Rondon, E.O.; Hume, M.E.; Hernandez, C.; ClementeHernandez, S. 2006. Intestinal microbial ecology of broilers vaccinated and challenged with mixed Eimeria species, and supplemented with essential oil blends. Poultry Science 85: 854-860.

Panigrahi, P.; Gewolb, I.H.; Bamford, P.; Horvath, K. 1997. Role of glutamine in bacterial transcytosis and epithelial cell injury. Journal of Parenteral and Enteral Nutrition 21: 75-80.

Perez-Carbajal, C.; Caldwell, D.; Farnell, M.; Stringfellow, K.; Pohl, S.; Casco, G.; Pro-Martinez, A.; Ruiz-Feria, C.A. 2010. Immune response of broiler chickens fed different levels of arginine and vitamin E to a coccidiosis vaccine and Eimeria challenge. Poultry Science 89: 1870-1877.

Pluske, J.R.; Thompson, M.J.; Atwood, C.S.; Bird, P.H.; Williams, I.H.; Hartmann, P.E. 1996. Maintenance of villus height and crypt depth, and enhancement of disaccharide digestion and monosaccharide absorption, in piglets fed on cows' whole milk after weaning. British Journal of Nutrition 76: 409-422.

Pohlenz, C.; Buentello, A.; Bakke, A.M.; Gatlin III, D.M. 2012. Free dietary glutamine improves intestinal morphology and increases enterocyte migration rates, but has limited effects on plasma amino acid profile and growth performance of channel catfish Ictalurus punctatus. Aquaculture 370: 32-39.

Rhoads, J.; Argenzio, R.; Chen, W.; Rippe, R.; Westwick, J.; Cox, A.; Berschneider, H.; Brenner, D. 1997. L-glutamine stimulates intestinal cell proliferation and activates mitogenactivated protein kinases. American Journal of PhysiologyGastrointestinal and Liver Physiology 272: G943-G953.
Rostagno, H.S.; Albino, L.F.T.; Donzele, J.L.; Gomes, P.C.; Oliveira, R.F.; Lopes, D.C.; Ferreira, A.S.; Barreto, S.L.T.; Euclides, R.F. 2011. Brazilian Tables for Poultry and Swine: Composition of Feedstuffs and Nutritional Requirements = Tabelas Brasileiras para Aves e Suínos: Composição de Alimentos e Exigências Nutricionais. 3ed. Editora UFV, Viçosa, MG, Brazil (in Portuguese).

Sakamoto, M.; Murakami, A.; Silveira, T.; Fernandes, J.; Oliveira, C.A.L. 2006. Influence of glutamine and vitamin $\mathrm{E}$ on the performance and the immune responses of broiler chickens. Revista Brasileira de Ciência Avícola 8: 243-249.

Scheurer, W.; Spring, P.; Maertens, L. 2013. Effect of 3 dietary phytogenic products on production performance and coccidiosis in challenged broiler chickens. The Journal of Applied Poultry Research 22: 591-599.

Sharman, P.A.; Smith, N.C.; Wallach, M.G.; Katrib, M. 2010. Chasing the golden egg: vaccination against poultry coccidiosis. Parasite Immunology 32: 590-598.

Soltan, M. 2009. Influence of dietary glutamine supplementation on growth performance, small intestinal morphology, immune response and some blood parameters of broiler chickens. International Journal of Poultry Science 8: 60-68.

Stringfellow, K.; Caldwell, D.; Lee, J.; Mohnl, M.; Beltran, R.; Schatzmayr, G.; Fitz-Coy, S.; Broussard, C.; Farnell, M. 2011. Evaluation of probiotic administration on the immune response of coccidiosis-vaccinated broilers. Poultry Science 90: 1652-1658.

Torres, K.A.; Pizauro, J.M.; Soares, C.P.; Silva, T.G.; Nogueira, W.C.; Campos, D.M.; Furlan, R.L.; Macari, M. 2013. Effects of corn replacement by sorghum in broiler diets on performance and intestinal mucosa integrity. Poultry Science 92: 1564-1571.

Vermeulen, A.N.; Schaap, D.C.; Schetters, T.P. 2001. Control of coccidiosis in chickens by vaccination. Veterinary Parasitology 100: $13-20$.

Walk, C.; Cowieson, A.; Remus, J.; Novak, C.; McElroy, A. 2011. Effects of dietary enzymes on performance and intestinal goblet cell number of broilers exposed to a live coccidia oocyst vaccine. Poultry Science 90: 91-98.

Wang, J.Y.; Li, J.; Patel, A.R.; Summers, S.; Li, L.; Bass, B.L. 1998. Synergistic induction of ornithine decarboxylase by asparagine and gut peptides in intestinal crypt cells. The American Journal of Physiology 274: C1476-C1484.

Williams, R.B. 2002. Anticoccidial vaccines for broiler chickens: pathways to success. Avian Pathology 31: 317-353.

Wilmore, D.W.; Smith, R.; O'dwyer, S.; Jacobs, D.; Ziegler, T.; Wang, X.D. 1988. The gut: a central organ after surgical stress. Surgery 104: 917-923.

Yi, G.; Allee, G.; Knight, C.; Dibner, J. 2005. Impact of glutamine and oasis hatchling supplement on growth performance, small intestinal morphology, and immune response of broilers vaccinated and challenged with Eimeria maxima. Poultry Science 84: 283-293. 